\title{
Research on the Dilemma and Countermeasures of Engineering Postgraduate Entrepreneurship in Local Universities*
}

\author{
Yue Cai \\ Wuhan University of Science and Technology \\ Wuhan, China
}

\author{
Ming $\mathrm{He}$ \\ Wuhan University of Science and Technology \\ Wuhan, China
}

\begin{abstract}
Postgraduate entrepreneurship is the call of the times. And it has certain advantages. Due to the influence of many factors inside and outside the universities, the engineering postgraduates would have enormous difficulties in the entrepreneurship period. Local colleges and universities can actively conduct entrepreneurship education, implement classified guidance, use good entrepreneurial support policies, provide entrepreneurial platforms, conduct simulations and undertake ventures, and implement risk assessments. And then, they could stimulate entrepreneurial desires and potentials of engineering postgraduates.
\end{abstract}

Keywords-local colleges and universities; engineering; postgraduates; entrepreneurship; dilemma; countermeasures

\section{INTRODUCTION}

As early as September 2014, in the Summer Davos Forum, Prime Minister Li Keqiang had issued the call for "mass entrepreneurship and innovation." At the Third Session of the Twelfth National People's Congress, Premier $\mathrm{Li}$ Keqiang of the State Council made the report on government work. He explicitly stated "mass entrepreneurship and innovation". With the new normal economy, traditional industries are under tremendous pressure. It is necessary for Premier Li Keqiang to put forward "mass entrepreneurship and innovation" in a timely manner on the basis of integrating China's national conditions and the current international situation and conforming to the development of the times. "Mass entrepreneurship and innovation" will be the policy direction for a long time to come, and is also the direction of the government's efforts. At present, it is the best time to start a business. The postgraduates are the most creative group. And they are in the most creative age. They should go out to start a business, and have a try. However, from the current

*Fund Project: "Study on training model of postgraduate entrepreneurship education and innovative talents". Humanistic Social Science Research Project of the Department of Education in Hubei Province (Project No.: 16Z026); "Iron spirit education and moral education innovation of postgraduate in metallurgical colleges". It is specialized project of Hubei province in 2017 (Project No.: 2017SJJPC3010); "Exploration and Practice of Practical Education System for Full-time Graduates of Major Degree" of Wuhan University of Science and Technology Graduate Quality Engineering Project in 2017 (Project No. Yjg201722) situation of local colleges and universities, the number of postgraduate entrepreneurship is small. Especially, the entrepreneurial motivation of engineering postgraduates is obviously inadequate.

\section{SignifiCANCE OF PostgRaduATE \\ ENTREPRENEURSHIP IN LOCAL UNIVERSITIES}

The local comprehensive university has the localization and the development goal. It is based on the local situation. And it would serve the local economy. It needs to undertake more training work adapting to the characteristics of local economic development of entrepreneurial, creative personnel training work. Compared with junior college students and graduate students, the postgraduates have the advantages of more mature and rational ideology, stronger scientific research ability. They would have higher success rate of entrepreneurship. And they would be important group of entrepreneurial talents [1].

Local colleges and universities are closely linked to local areas. They are aware of local needs. It can actively serve the local economy. Also, they could adapt to local enterprises and market needs. And it can flexibly adjust postgraduate training process. As far as engineering postgraduates are concerned, they have their own characteristics. And their training process is quite different from that of postgraduates in other disciplines. Engineering postgraduates have been trained in scientific research for a long time. And the research and study is more close to the core engineering technology. Also, they are more closely related to the specialty in the practice of enterprise. It is more possible to make innovation in engineering technology. And then, it would speed up the process of high-tech industrialization. Greatly speaking, it would alleviate the problem of low conversion rate of scientific research in China [2]. 


\section{ThE STATUS QUO AND DifFICUlTIES OF ENGINEERING POSTGRADUATE ENTREPRENEURSHIP IN LOCAL UNIVERSITIES}

\section{A. The Status of Engineering Postgraduate Entrepreneurship in Local Universities}

Local colleges and universities are facing the competition of the students of the subordinate colleges and universities. No matter in the quality of postgraduates, teachers, or scientific research platform, disciplines, training and so on, there is a big gap with it. In the aspect of entrepreneurship, it also faces large gap. According to the relevant statistics, the number of postgraduates who start their own businesses is not as large as the number of undergraduates who start their own businesses every year. "Table I" shows the number of postgraduate and the statistics of entrepreneurship in a local university in Hubei province in recent five years.

TABLE I. STATISTICS ON THE NUMBER OF POSTGRADUATES AND ENTREPRENEURSHIP IN A LOCAL UNIVERSITY IN THE PAST FIVE YEARS

\begin{tabular}{lll}
\hline Subject Category & Number & Number of entrepreneurs (person) \\
Engineering & 3862 & 15 \\
Neo-Confucianism & 195 & 0 \\
Medicine Industry & 160 & 0 \\
Cultural 1796 & 12 \\
Management & & \\
\hline
\end{tabular}

From "Table 1", we can see that the total number of postgraduates in local universities in recent five years is 5833. And entrepreneurship is limited to engineering and liberal arts postgraduates. And the number of postgraduates is 27 , accounting for $0.0046 \%$ of the total number of postgraduates. Among them, there are 3862 engineering postgraduates. The number of entrepreneurs is only 15 , accounting for $0.0039 \%$. And there are 12 postgraduates in the field of culture and management starting their own businesses. And the percentage of starting their businesses is $0.00668 \%$.

It is not difficult to see from the statistics table of the number of postgraduates and their entrepreneurship work in a local university in recent five years. Less than 5 postgraduates start their own businesses per 1,000 persons. And the number of entrepreneurship is low. Less than 4 postgraduates start their own businesses per 1,000 engineering postgraduates in local colleges and universities. And the number of entrepreneurship is smaller. The entrepreneurial motivation is significantly inadequate.

\section{B. The Entrepreneurship Difficulties of Engineering Postgraduates in Local Universities}

The entrepreneurship of engineering postgraduates is affected by many factors (see "Fig. 1"). The external environment mainly comes from the influence of society and schools. From the perspective of internal factors, it mainly comes from family and themselves. The social influencing factors mainly include the understanding of social demand, the collection of market information, the employment situation and the support of the state to the entrepreneurship. Undertaking education, arrangement of course study, requirement of tutor, requirement of experiment research and requirement of graduation condition will all affect the motivation of engineering postgraduate. The quality of postgraduates' family conditions and the degree of support are also the factors that cannot be ignored in postgraduates' entrepreneurship. The most important influencing factors of postgraduate entrepreneurship are their own reserves of entrepreneurial knowledge and theory, the courage to start a business, the financial security, the smooth formation of entrepreneurial talent team, and the management and leadership skills required by entrepreneurship.

According to a survey of 682 postgraduates from Beijing University of Commerce and Industry, more than 80 percent of the surveyed students showed an interest in entrepreneurship. And nearly 60 percent of them considered starting their own business [3]. For the colleges and universities of finance and cultural industry management, postgraduates have high enthusiasm for self-entrepreneurship. However, for the engineering postgraduates of local colleges and universities, based on the impact of the above factors, engineering postgraduates are facing a lot of difficulties and great challenges. The entrepreneurial enthusiasm is not high.

Affected by the international and domestic economy, the social demand for engineering postgraduate labor resources is large. The employment prospect of engineering postgraduates is relatively good. And it will lead to low entrepreneurial desire of engineering postgraduates [4]. At the same time, college teachers lack entrepreneurial experience and entrepreneurial knowledge reserves. And the teaching form and teaching model is simple. They lack teaching skills. The colleges and universities lack entrepreneurial education system. The theoretical framework of education is seriously out of step with the times. And the postgraduates lack adequate practical teaching and training [5]. There are many reasons, such as the lack of connection between postgraduates and society, the lack of understanding of society, the lack of understanding of information about social needs, the lack of understanding of information about social needs, and so on. It would lead to the lack of knowledge and theory about entrepreneurship among postgraduates. It is very difficult to find the breakthrough point of entrepreneurship, which leads to the vague intention of entrepreneurship and slow action.

In addition, engineering postgraduates will face great challenges in their personal courage, the reserve of management ability, the preparation of venture capital, the channels of market development and the selection of team members, and so on. 


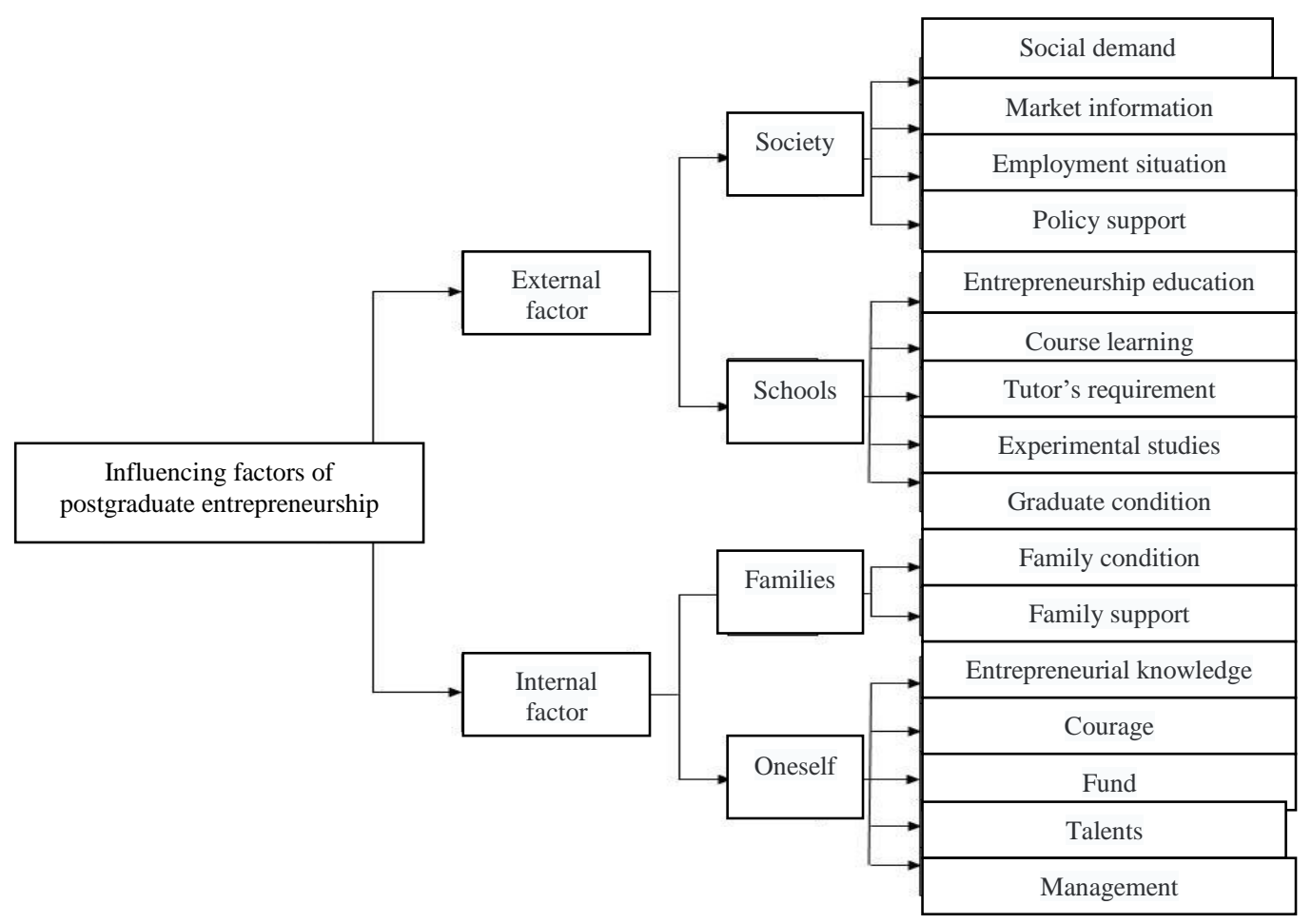

Fig. 1. Influencing factors of postgraduate entrepreneurship.

\section{ENTREPRENEURIAL COUNTERMEASURES OF}

\section{ENGINEERING POSTGRADUATES IN LOCAL UNIVERSITIES}

The entrepreneurship of engineering postgraduates in local colleges and universities is affected by many factors. To make full use of the current excellent environment, provide a better entrepreneurial environment for engineering postgraduates and allow more engineering postgraduates to participate in entrepreneurship is an urgent problem that needs to be solved.

Sun Jin, a doctoral student in automation of Tsinghua University, believes that one of the most important factors of the success is whether it matches with the capabilities. He also points that not everyone is fit to start a business. Entrepreneurship puts big test on strategic vision, knowledge structure, execution, resource integration ability, mind, tenacity and even the luck [6]. Therefore, in order to conform to the development of the times and serve the local economy better, the local engineering colleges must strengthen the guidance to the engineering postgraduates, create conditions and platforms for the engineering postgraduates in many aspects and measures, and introduce a series of favorable policies to encourage engineering postgraduates to participate in the entrepreneurship.

\section{A. To Carry out Entrepreneurship Education and Classified Guidance Actively}

The characteristics of local colleges and universities are obvious. Engineering postgraduates have high professional knowledge. And they have accounted for a large proportion. If we can make full use of the characteristics of local colleges and universities and the characteristics of engineering postgraduates, it should strengthen the entrepreneurship education and classification guidance to engineering postgraduates. And then, it can realize the "public entrepreneurship".

Local colleges and universities should energetically carry out the guidance of postgraduate entrepreneurship curriculum, reasonably formulate the entrepreneurship education curriculum for postgraduate entrepreneurship education from the aspects of humanity, education, psychology, society, finance and management, and energetically cultivate the knowledge of humanities, society, psychology and management of engineering postgraduates. And then, it would increase the courage of postgraduates. The postgraduates should strengthen exercise, improve the ability of expression, increase the training and the knowledge of financial management, and enhance the sense of cooperation. Then, they would have the ability to form a like-minded entrepreneurial team. The colleges and universities should rationally construct the training system of engineering postgraduate entrepreneurship education. And the postgraduates would have and master the necessary knowledge of entrepreneurship. It may lay a good foundation for the entrepreneurship of postgraduates.

According to the classification of postgraduates and the different functions entrusted by the Ministry of Education, the colleges and universities should pay attention to the cultivation of innovative ability and academic research ability of the academic engineering postgraduates. And the colleges and universities should pay attention to the cultivation of professional practice and entrepreneurial ability of the professional engineering postgraduates. The professional engineering postgraduates are more suitable to 
have the entrepreneurship education [8]. Local colleges and universities can choose entrepreneurship education models of "the type of business school" and "the type of engineering school" according to their own reality. And "the type of business school" is suitable for the colleges and universities of finance and cultural industry management. It is suitable for good business education and start-up enterprises. The "type of engineering school" is suitable for colleges and universities which have a solid foundation in engineering. They want to make breakthrough and innovation in engineering technology. Also, they would popularize and commercialize engineering technology [9]. To carry out classified guidance of postgraduate entrepreneurship education is an effective way to give full play to the specialty characteristics of local universities and engineering graduate students.

\section{B. To Make Good Use of Entrepreneurship Support Policy and Provide Entrepreneurship Platform}

At present, the state and local governments have issued preferential policies to encourage university students and postgraduates to start their own businesses. And the support is unprecedented. Not only that, the state and the local governments continues to launch the entrepreneurship design competition, and provide a large number of funds and financial support. They provide a broad platform for college students to have entrepreneurship. However, it did not play a very good expected effect from the actual implementation. The main reason is that most colleges and universities do not have the corresponding policies. The schools have few fulltime competent departments to carry out the guidance of graduate entrepreneurship. It lacks entrepreneurial atmosphere. The postgraduate tutor doesn't have enough supports for the entrepreneurship. Even some supervisor does not support them at all. The tutor wouldn't guide the students to start the business. The students of engineering are busy experimenting, writing and publishing papers. And then, they can graduate smoothly. A small number of colleges and universities want to complete the typical indicators issued by the higher departments of entrepreneurship. They don't hesitate to make up the number, blindly report some of the projects without market potential. And they would transfer the project of the mentor's entrepreneurship into the project of student entrepreneurship and so on.

Therefore, local colleges and universities should clarify the train of thought and attach great importance to graduate entrepreneurship. They should adjust and optimize the training scheme of graduate students in engineering specialty, reduce the class hours of theoretical study, increase the time of entrepreneurship education and practice, and create a good academic and entrepreneurial practice environment [10]. It should strengthen cooperation with enterprises, and actively carry out the combination of industry, university and research. Also, it should promote the industrialization of tutor project and enterprise tutor system, and integrate tutor subject into postgraduate course study and practice. And then, it should make full use of all kinds of supporting policies, mobilize the whole university to cooperate with the local departments concerned, and effectively create convenient conditions for engineering postgraduates to start their own businesses. The universities should carry out the social practice in an all-round way, and extend the social practice of graduate students to all ways of life. It should ensure that the social practice cannot be less than one year. Also, it should create more opportunities for postgraduates to exercise and start their own businesses.

Local governments and educational authorities, local colleges and universities should cooperate closely, invite well-known enterprises to participate in it, and give guidance to local colleges and universities with practical actions, rather than simply issuing documents to the requirements of colleges and universities. Local government and educational authorities should fully exercise administrative rights, do a good job of local overall planning needs, and determine the key market R \& D products, science and technology projects. The local colleges and universities should participate in product R \& D, science and technology project innovation. Local enterprises are required to provide practice opportunities for local colleges and universities. And it should hold regular market demand conferences and other measures, and strive to provide local colleges and universities with more practice opportunities and entrepreneurial information.

\section{To Organize and Conduct Simulation Entrepreneurship and Implement Risk Assessment}

The department of education can jointly develop the enterprise simulation system and enterprise risk assessment system with the software development company. It can be used to carry out the enterprise education in colleges and universities. Local colleges and universities must set up a guidance office for college students and postgraduates. And they should strengthen the guidance for the entrepreneurship of college students and postgraduates. The colleges and universities should set up simulation entrepreneurship courses and entrepreneurship risk assessment courses. Also, they should regularly organize postgraduate to visit local start-up parks or some large enterprise companies.

Local universities should also invite local enterprises to participate in postgraduate entrepreneurship education. The colleges and universities should often carry out the activities of simulating sand-table entrepreneurship, entrepreneurship salon, entrepreneurship forum, entrepreneurship simulation competition and so on. They should invite the related experts to set up venture risk assessment team to assess the risk of engineering postgraduate entrepreneurship. And the experts would give scientific guidance on the spot, and put forward reasonable and constructive suggestions. Through the activities of simulating entrepreneurial risk assessment, the postgraduates are familiarized with the basic business process. And they would have preliminary experience in entrepreneurial combat. It could fully arouse the desire of the majority of engineering postgraduates to start their own businesses. And it could stimulate entrepreneurial potential. 


\section{CONCLUSION}

Postgraduate entrepreneurship is the call of the times. And they would have certain advantages. Entrepreneurship of engineering postgraduates in local colleges and universities is currently on the low side. At the same time, there are many problems in starting an undertaking. In order to solve these problems, it is necessary to further study which factors affect the entrepreneurial tendency of engineering postgraduates in local colleges and universities. Also, we should study what the relationship between these factors is, and how these factors influence the emergence and formation of entrepreneurial tendency. Based on these factors, this paper puts forward some suggestions to encourage the engineering postgraduates to start an undertaking. Entrepreneurial quality is the inherent decisive factor. Entrepreneurial environment is the necessary condition, and entrepreneurial practice is the fundamental way. We should study the interaction among the three factors. Local colleges and universities should stimulate the entrepreneurial desire and potential of engineering postgraduates by actively carrying out entrepreneurial education and classification guidance, making good use of entrepreneurial support policy, providing entrepreneurial platform, carrying out simulation entrepreneurship, implementing risk assessment and other measures. Of course, it is impossible for colleges and universities to complete entrepreneurial education independently. It needs the joint support of governments, enterprises and institutions at all levels. And then, it would be carried out effectively.

\section{REFERENCES}

[1] Chen Lidong, Wen Yanbing, Wang Huqing. Study on cultivation of postgraduate entrepreneurial talents in local comprehensive universities[J]. Journal of Ningbo University (Education and Academic Edition), 2014, 36(5): 53-57. 陈利东, 文雁兵, 王湖青. 地方综合性大学研究生创业型人才培养调查 $[\mathrm{J}]$. 宁 波大学 学 报：教育科学版，2014，36（5）：53-57.

[2] $\mathrm{Su} \mathrm{Ke}, \mathrm{Hu}$ Guangming. Interpretation of postgraduate employment dilemma in China and Construction of postgraduate self-employment system[J]. Academic Degrees \& Graduate Education, 2008(9):63-68. 苏柯, 胡光明.解读我国研究生就业困境构建研究生自主创业体 系 $[\mathrm{J}]$. 学位与研究生教育, 2008 (9) : 63-68.

[3] Li Zhengqiong. No longer seeking stability - $80 \%$ of post-90s postgraduate wants to have entrepreneurship [EB/OL]. (2014-1210)[2016-07-18] $\quad$ http://news.youth.cn/wztt/ 201412/t20141210_6212784.htm. 李正穹.不再 “求稳” 90 后研究 生群体八成想创业 [EB/OL]. (2014-12-10) [2016-07-18]. http://news.youth.cn/wztt/201412/t20141210_6212784.htm.

[4] Xie Hongmei,Gong Huixiang,Peng Liping,An Analysis of Postgraduate Entrepreneurial Tendency and Entrepreneurial Demand - Based on a Survey of Zhejiang University[J]. Academic Degrees \& Graduate Education, 2012(4):48-52. 谢红梅, 龚惠香, 彭列平等, 研究生创业倾向与创业需求分析一基于浙江大学的调 查 $[\mathrm{J}]$.学位与研究生教育, 2012（4）：48-52.

[5] Zhao Dawei. Characteristics, problems and countermeasures of postgraduate entrepreneurship education in $\mathrm{China}[\mathrm{J}]$. Academic Degrees \& Graduate Education, 2008(6):36-39. 赵大伟.我国研究生 创业教育的特点、问题与对策 $[\mathrm{J}]$. 学位研究生教育, 2008（6）: 36-39.

[6] Wang Mengying, Cheng Mengchao. The way to be entrepreneurs for engineering students in Tsinghua University [EB/OL]. (2015-0922)[2016-07-18]. http://chuangye.cyol.com/content/2015-09/ 22/content_11643080.htm. 王梦影, 程盟超.清华学霸工科男如何
转 型 创 业 者 [EB/OL]. (2015-09-22) [2016-07-18]. http://chuangye.cyol.com/content/2015-09/22/content_11643080.htm.

[7] Wang Xingfen. Research on postgraduates' innovation and entrepreneurship education in the post-financial collection age $[\mathrm{J}]$ Journal of Higher Education, 2010(12):22-26. 王杏芬.后金融文集时 代的研究生创新创业教育研究 [J] . 高等教育研究, 2010 (12): 22-26.

[8] Shi Pengcheng. A preliminary study on entrepreneurship education of full-time postgraduates [J]. Abroad and Employment, 2010(9):75-76. 施鹏程. 全日制专业学位硕士研究生创业教育初探 [J].出国与就 业，2010（9）：75-76.

[9] You Zhensheng. Research on entrepreneurship education in American colleges and universities [D]. Chongqing: School of Education, Southwest University, 2011:192-193. 游振声.美国高等学校创业教 育研究[D].重庆: 西南大学教育学院, 2011：192-193.

[10] Yan Yuxiang. The realistic dilemma and outlet for self-employment of postgraduates in China under current situation [J]. Education Work 2009:74-75. 鸟玉香.当前形势下我国研究生自主创业的现实困境 与出路 $[\mathrm{J}]$.教育工作, 2009: 74-75. 